\title{
Memoria e imaginación. Colecciones de lectura para contar la violencia política en la literatura infantil argentina (1970-1990)
}

\section{עaura Rafaela García / Universidad Nacional de Tucumán - CONICET / lau2garcia@hotmail.com}

\section{Resumen}

Este estudio se organiza a partir de tres ejes centrales: memoria, literatura e infancia. El interrogante sobre cómo contar el pasado reciente a los niños dio lugar a la indagación de la literatura infanto-juvenil argentina. Para avanzar en la exploración de esta zona cultural - escasamente abordada por los estudios literarios - distinguimos dos grupos de narrativas del pasado (Jelin) que nos permiten interpelar las formas de organizar distintos corpus de lecturas en las prácticas literarias actuales. Por un lado, analizamos los movimientos de una formación de agentes culturales comprometidos con la infancia desde el lenguaje estético que, entre los setenta y los noventa, transita distintos momentos y logra ampliar el espesor de un campo que se define por la interpelación a la imaginación en los textos literarios para niños. Por otro, abordamos las formas soterradas de aludir a la violencia política en la literatura infanto-juvenil organizadas en tres colecciones de lecturas que contribuyen a ampliar las representaciones ficcionales del imaginario colectivo por medio de las situaciones narrativas. En síntesis, este trabajo se inscribe en los límites borrosos existentes entre memoria e imaginación y desde esa zona se propone ampliar las formas de transmitir la violencia política desde los protocolos de la ficción en la literatura argentina para niños.

Palabras clave: memoria $\cdot$ violencia política $\cdot$ protocolos de ficción $\cdot$ literatura infantil $\cdot$ modos de leer

\section{Abstract}

This study is organized around three central themes: memory, literature and childhood. The question of how to count the recent past children led to the investigation of children's literature Argentina. To further explore this cultural area, largely untouched by literary studies, we distinguish two groups of narratives of the past (Jelin) that allow us forming forms challenged the literary corpus in $\mathrm{cu}^{-}$ rrent practices. On the one hand, we analyze the movements of a cultural agent training committed to children from the aesthetic language, between seventy and ninety, different times and achieved passes expand the thickness of a field that is defined by the interpellation to the imagination in literary texts for children. On the other, we address the underground ways of referring to political violence in children's literature organized in to three collections of readings that help to broaden the 
collective imaginary fictional representations through narrative situations. In summary, this work fits into existing blurred boundaries between memory and imagination and since that area is proposed to extend the methods of transmitting political violence since the protocols of fiction.

Key words: memory $\cdot$ political violence $\cdot$ protocols of fiction $\cdot$ children's literatura $\cdot$ reading modes
El pueblo entero se arrugó de miedo.

De miedo a que lo comieran. Porque ya se sabe que los ogrontes, cuando se enojan, se comen pueblos enteros, con sus casas, sus personas, sus calles y sus kioscos. Y sus perros. Y las petunias de sus jardines. Y sus tarros de galletitas. Y sus boletos capicúa. Y sus estaciones, con trenes y todo.

La gente salió corriendo. Algunos iban con las orejas tapadas (taparse las orejas no protegía del enojo del ogronte, pero al menos ayudaba a que sus rugidos molestasen menos). Pero yo dije al principio que éste era el cuento de un pueblo, de un ogronte y de una nena. Ahí está la nena —_la ven?-; es esa de rulitos en la cabeza: Irulana. Es la única que no corre.

Graciela Montes («Irulana y el ogronte»)
Fecha de recepción: 4/9/20I4

Fecha de aceptación: $4 / 12 / 2014$

¿Cómo se cuenta la violencia política en la literatura infanto-juvenil argentina? A partir de este interrogante iniciamos la exploración por el campo literario argentino y tomamos como punto de partida un criterio histórico al considerar como principal hecho violento la última dictadura militar argentina (1976-1983). Empezamos por rastrear las referencias soterradas a la violencia política en los textos ficcionales publicados entre 1970 y 1990 por autoras como María Elena Walsh, Laura Devetach, Elsa Bornemann, Graciela Montes, entre otras.

Este trabajo ${ }^{1}$ se propone ampliar el corpus de las prácticas literarias actuales y explorar una zona cultural pocas veces analizada desde los estudios literarios, que en muchos casos atribuye a la literatura infanto-juvenil las connotaciones de lo menor (Díaz Rönner 200o) en relación con el sentido general de lo infantil como lo carente de lenguaje y de experiencia. La puerta de entrada al campo fue la lectura de los relatos ficcionales que, a partir de las investigaciones de memoria realizadas por Elizabeth Jelin, fueron entendidos como narrativas del pasado. Este concepto es el eje central de la investigación y apunta a aquellos relatos comunicables que contribuyen a la construcción de sentidos del pasado - como lo demuestra Jelin- y dejan ver la complejidad de los tejidos en su enlace con el presente y la influencia de los marcos de encuadramiento social desde los cuales es posible rememorar y resignificar el pasado.

La indagación por este período en la literatura infantil argentina reveló la importancia de un corpus de textos de la crítica producidos por las mismas autoras de ficción, que recuperaron las principales discusiones del campo entre los años sesenta y setenta. En consecuencia, el concepto de narrativas del pasado de Jelin se amplió para abarcar no sólo los textos ficcionales y sus referencias simbólicas a 